Burgess, P.J. \& Morris, J. Agricultural technology and land use features. Land Use Policy, Vol.26, Supplement 1, pages S222-S229, December 2009

DOI: 10.1016/j.landusepol.2009.08.029

\title{
Agricultural Technology and Land Use Futures: the UK case
}

Paul J. Burgess and Joe Morris

School of Applied Sciences, Cranfield University, Cranfield, Bedfordshire, MK43 OAL Corresponding author: P.Burgess@ cranfield.ac.uk

\begin{abstract}
This paper explores how agricultural technology has interacted with recent land use in the UK and how it might do so in the next 50 years. From 1960 to 1985, farmers successfully used technology to increase the output of crop and animal products per unit of land and particularly of labour. This reduced the number of people employed in agriculture, and promoted larger and more specialised farm enterprises. Between 1985 and 2006, food prices were relatively low, and although labour productivity continued to increase, land productivity remained relatively static. However during this period, farmers started to address the effects of agriculture on reduced water quality and habitat loss.

For established agricultural products, technological innovation tends to have an incremental effect, working through genetic improvement, the removal of abiotic and biotic stress (e.g. crop nutrition and protection, irrigation and drainage, and animal nutrition, health and housing) and the substitution of labour. Whereas the first two processes tend to be scale-neutral, the substitution of labour is usually best achieved on larger farms. Other key areas for technological innovation include addressing air, soil and water quality, biodiversity, waste reduction, and information management. Over the next 50 years, large step changes in land use arising from agricultural technology are predicted to arise from the development of new markets for agricultural products. A strong bioenergy sector will strengthen the links between crop commodity and energy prices and will have a major effect on future land use. Climate change and the regulation of greenhouse gas emissions will alter the relative profitability of crop and animal production systems. Lastly, increased public awareness of the links between food, health and the environment could substantially shift the demand for specific agricultural products

Continual improvements in agricultural technology are pivotal to providing society with the flexibility to balance the challenges of improving human well-being with the management of the planet's ecosystem. Increased technological innovation increases the probability that agricultural land can be used for other purposes, but their exact relationship is dependent on trade and environmental policies. The large external effects of agriculture mean that decisions regarding the adoption of future technologies should be taken by farmers working with other stakeholders.
\end{abstract}

Key words: Agriculture, Technology, Land, Productivity, Farming Systems, UK 


\section{Introduction}

The aim of this paper is to explore the relationships between agricultural technology and land use. The rate and direction of technology change (together with changes in population, economic growth, governance, and social values) are key drivers determining future land use (Berhout et al., 1998). Within this paper, agricultural technology is defined as the application of knowledge, science, engineering and management in crop and animal production systems. Any agricultural system can be considered as a group of interacting components that has a boundary within which inputs are managed to produce outputs (Figure 1).

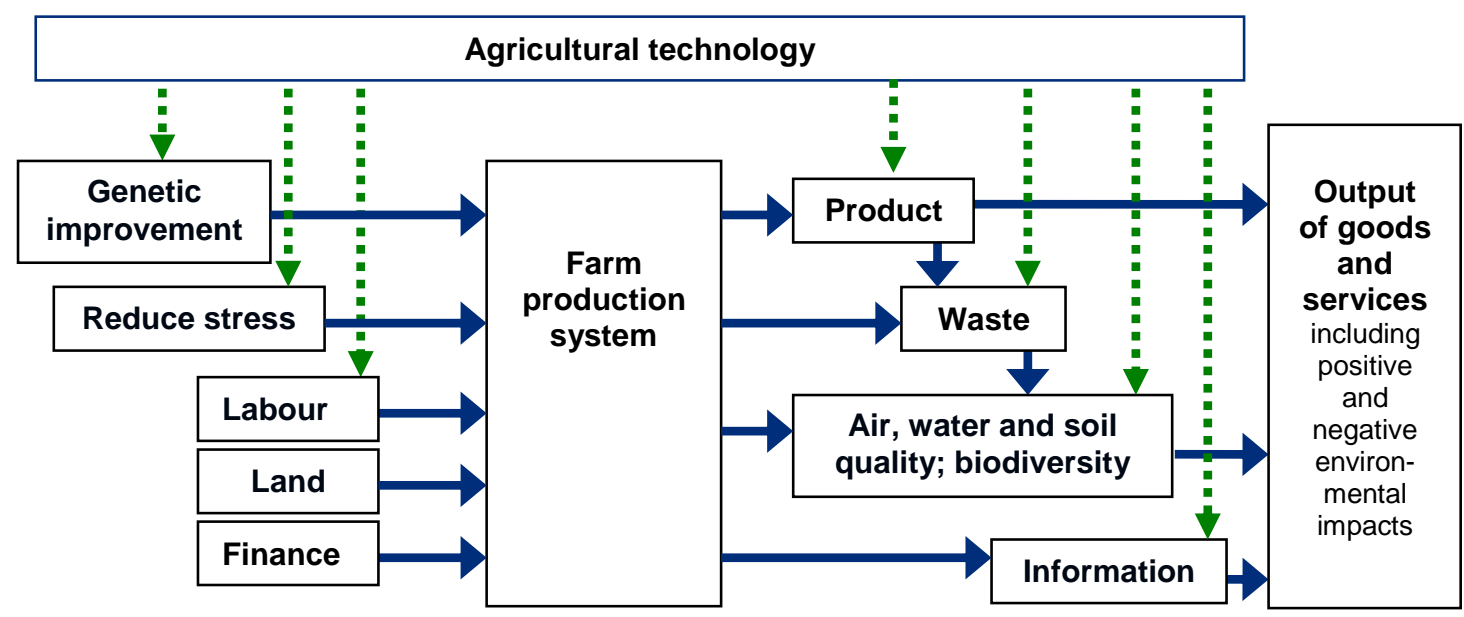

Fig 1. Schematic diagram showing how a farmer uses land, labour, finance, genetic improvement and husbandry methods as key inputs to a farm production system, which results in output such as products, waste, environmental services, and information. There are seven key areas (indicated by the vertical dotted lines) where technology can affect agricultural systems and thereby land use.

During much of the $20^{\text {th }}$ century, a typical aim of a farm enterprise was to maximise the production of crop and animal products in terms of the three key inputs (land, labour, and finance) (Figure 1). For a given system, this could be done by breeding better crops or animals, reducing abiotic and biotic stresses on those crops and animals, and substituting labour (Figure 1). Whilst the production of crop and animal products provides the financial framework for most farm enterprises, most farmers have a cultural interest in maintaining the quality of air, water and soil resources and the biodiversity on their farm (Stoate et al., 2001). Since the mid-1980s, greater public awareness of some of the negative effects of agricultural systems on air, water and soil quality (Stoate et al., 2001) and biodiversity (Robinson and Sutherland, 2002), have led to the creation of regulations, financial instruments, and technologies to address these issues.

\section{Case studies}

Using wheat and milk as case studies, the paper firstly reviews the historic role of breeding and "stress reduction" on increasing production per unit land or per cow. This is followed by a consideration of labour productivity and total factor productivity. The second half of the paper examines how technological developments in the seven areas identified in Figure 1 may affect agricultural production over the 
next 50 years. Many of the areas are linked, but their combined effect will determine, in part, the capacity of the UK to release land from agricultural production. The main conclusions are outlined in the final section.

\section{Wheat production}

Since the 1990s, wheat has been the dominant arable crop in UK and is currently grown on about 40 per cent of the arable area of England. This dominance followed the development of the Chorleywood bread process in the early 1960s which allowed bakers to increase the proportion of British wheat within their flour blends (RussellEggitt, 1977). Through a range of technologies, the mean yield of wheat in the UK has increased from about 4 tonnes per hectare in the 1960s to about 8 tonnes per hectare in 2005 (Figure 2), similar to the increases observed in neighbouring countries such as Germany. The importance of weather on yield is apparent from the low yields due to drought in 1976, and high yields in 1984 when a cool wet spring and early summer was followed by dry harvesting conditions (Figure 2).

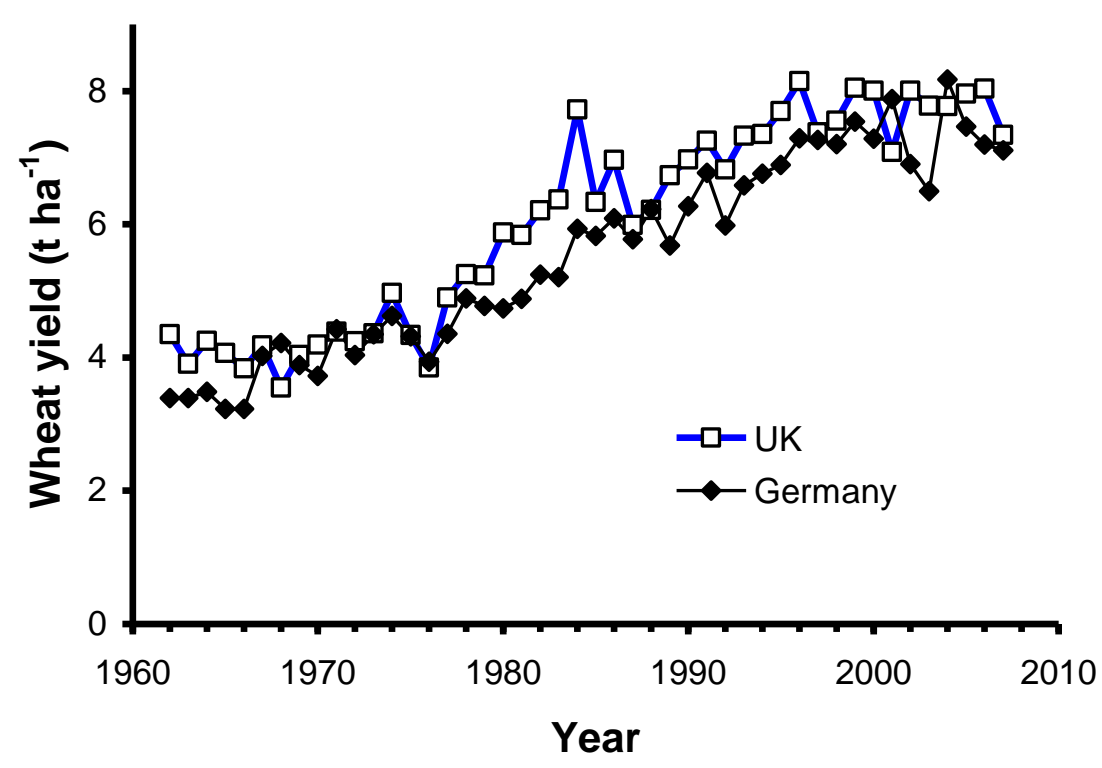

Figure 2. Annual wheat yields in the UK and Germany from 1962 to 2007 (FAO, 2009).

Austin et al. (1980) estimated that plant breeding contributed about 40 per cent of the cereal yield increase observed between 1947 and 1977. Breeders focussed on developing short-strawed varieties that allocated a higher proportion of biomass to grain and were more resistant to lodging, i.e. the collapse of straw. New varieties also tended to flower earlier and thereby had a longer period of grain-filling (Austin, 1999). Although increasing carbon dioxide concentrations have been beneficial, Austin (1999) attributes less than 5 per cent of the yield increase to this factor.

The majority of the remaining yield increase has resulted from farmers reducing the exposure of the crop to nutrient stress, weeds, pests and diseases. Applications of nitrogen to the UK wheat crop increased from about $28 \mathrm{~kg} \mathrm{ha}^{-1}$ in 1951, to $73 \mathrm{~kg} \mathrm{ha}^{-1}$ by 1962 (Austin, 1999) and to about $185 \mathrm{~kg} \mathrm{ha}^{-1}$ since 1985 . Following the introduction of the first selective herbicides in the 1940s, an increased frequency of the application of herbicides, fungicides and insecticides minimised weed competition and disease and pest damage. The use of growth regulators since the late 1960s has 
also allowed farmers to minimise yield losses due to stem breakage (e.g. lodging). Improved weed and pest management also enabled farmers to change from springplanted to autumn-planted varieties, and the simplification of crop rotations. Because autumn-planted varieties spend more time in the ground, they can intercept more solar radiation, produce more biomass and thereby provide higher yields. Although mean wheat yields stayed relatively constant between 1996 and 2007 (Figure 2), higher crops yields were still associated with greater profitability (Table 1).

Table 1. Comparison of yields $\left(\mathrm{t} \mathrm{ha}^{-1}\right)$ of winter wheat, winter barley, and oilseed rape on the 25 per cent of most profitable farms in the Eastern Counties of England compared with the mean farm (Lang, 2004).

\begin{tabular}{|c|c|c|c|c|c|c|}
\hline \multirow{3}{*}{$\begin{array}{l}\text { Crop } \\
\text { Year }\end{array}$} & \multicolumn{2}{|c|}{ Wheat } & \multicolumn{2}{|c|}{ Barley } & \multicolumn{2}{|c|}{ Oilseed rape } \\
\hline & 1989 & 1996 & 1989 & 1996 & 1989 & 1996 \\
\hline & -1995 & -2004 & -1995 & -2004 & -1995 & -2004 \\
\hline Top $25 \%$ & 8.8 & 9.2 & 7.0 & 7.0 & 3.6 & 4.1 \\
\hline Mean & 7.8 & 8.3 & 6.2 & 6.3 & 3.0 & 3.4 \\
\hline
\end{tabular}

\section{Milk production}

The dairy industry is currently the most important part of the UK livestock sector, as milk represents about one-third of livestock output and the sector provides about half the animals used in beef production. Technological innovation has allowed the mean annual milk yield per dairy cow to increase from about 3600 litres in the 1960s to over 7000 litres in 2005 (Figure 3). Similar increases have been observed in the Netherlands, Germany and France. Although there was a reduction following the imposition of quotas in 1984, the annual increase in productivity has been relatively consistent.

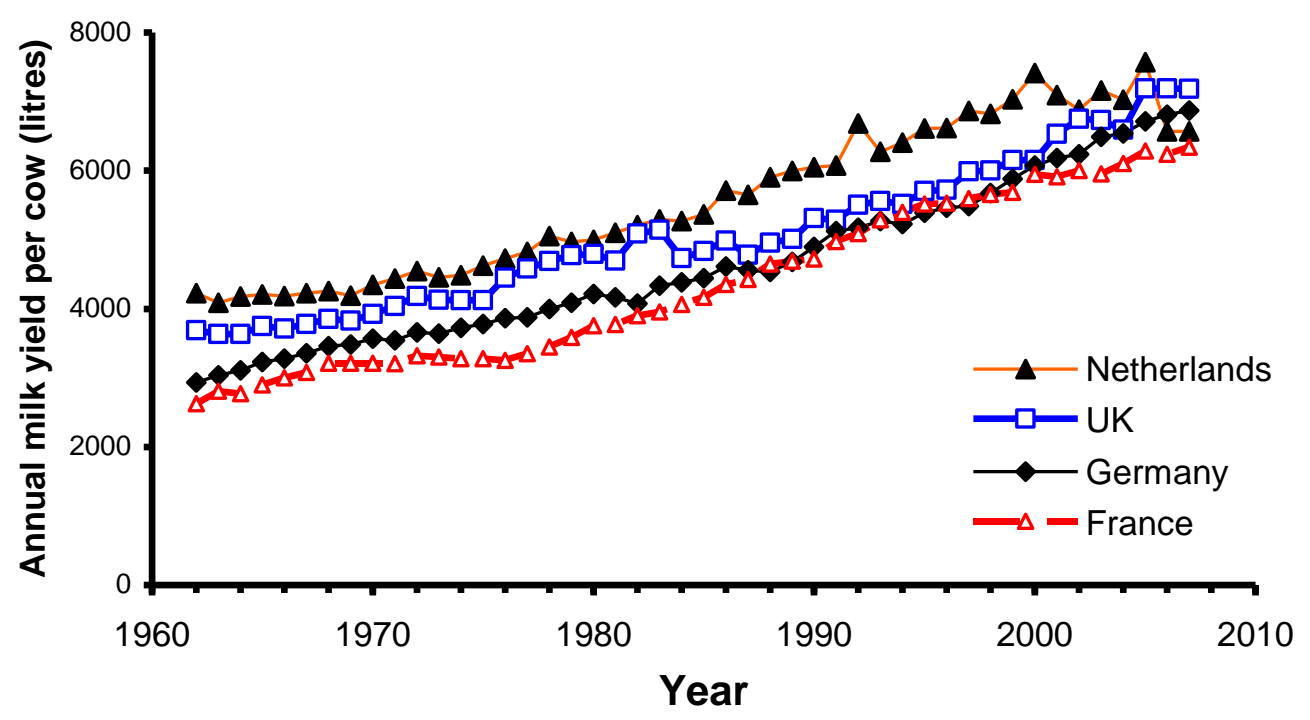

Figure 3. Observed milk yield per cow (FAO, 2009) in the Netherlands, UK, Germany and France from 1962 to 2007.

Pryce et al. (2004) has estimated that animal breeding and selection has contributed to up to 50 per cent of the improvement in milk yield over the past 25 years. This has primarily been related to the Friesian cattle being replaced by Holstein cattle, which 
tend to be larger and therefore can produce higher yields. The remaining proportion of the increase in productivity per cow has primarily been achieved by minimising any level of nutritional stress, and increasing the dry matter intake of feed with a higher nutrient density (Eastridge, 2006). There has been a move from the use of hay to grass-silage, and more recently maize-silage, systems. Detailed nutritional studies have been used to determine how "waste" products such as molasses, oilseed cake and brewers' grains can be incorporated into diets, and automated feeding means that feeding can be individually tailored for each cow. There have also been increases in the milk produced per area of land. Grass yields have increased as nitrogen application has increased from about $5 \mathrm{~kg} \mathrm{ha}^{-1}$ in the 1940 s to $120-130 \mathrm{~kg} \mathrm{ha}^{-1}$ in 1995 (Frame et al., 1995). Although not as extensive as the improvements in cereal yields, there have been improvements in the yield potential of ryegrass species (Cottrill et al., 2005).

\section{Labour productivity}

Although yields per hectare and yields per animal have increased steadily, the greatest increase in productivity has occurred in terms of output per hour of labour employed (Figure 4). This has primarily been achieved by investment in machinery and buildings (Bailey et al., 2004a).

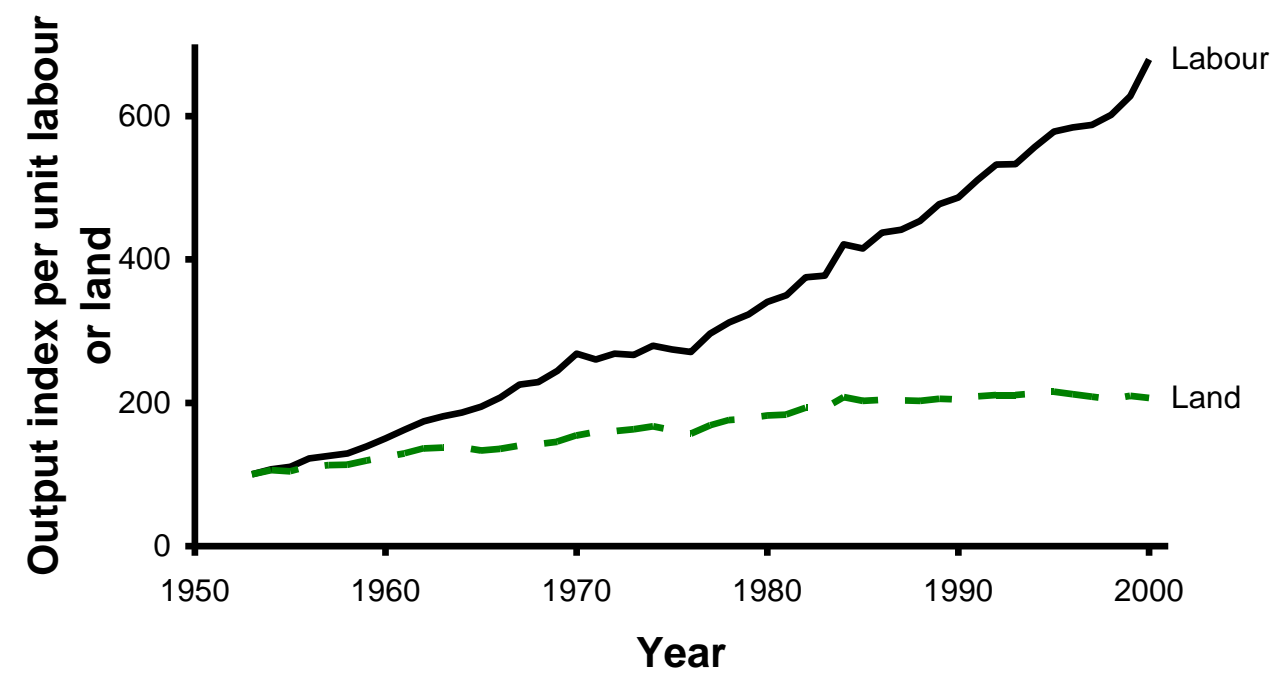

Figure 4 Levels of output per unit of land (dashed line) and unit of labour (solid line) between 1953 and 2000 (1953=100) (Thirtle and Holding, 2003).

In the crop sector, labour has been substituted by the introduction of chemical weed control, the use of wider cultivation, spray and harvesting equipment, and more powerful tractors. The mean power of a tractor in Eastern England increased from 70 $\mathrm{kW}$ in 1993 to $91 \mathrm{~kW}$ in 2003 (Lang, 2004). In the dairy sector, labour requirements per cow have been reduced by automated milking and feeding, and by the introduction of increasingly large mechanised parlours. The average herd size increased from 25 in 1965 to 74 in 2000 (Garnsworthy and Thomas, 2005). Associated with these changes, farmers have tended to increase field size. Across seven sites in England the mean field size increased from 5.6 ha in 1945 to 11.1 ha in 1994 (Westmacott and Worthington, 1997). During the same time period, the mean length of hedgerows across the seven sites fell from $137 \mathrm{~m} \mathrm{ha}^{-1}$ to $102 \mathrm{~m} \mathrm{ha}^{-1}$, and the 
number of mature and semi-mature trees decreased from $1.2 \mathrm{ha}^{-1}$ to $0.5 \mathrm{ha}^{-1}$ (Westmacott and Worthington, 1997).

\section{Total factor productivity}

Total factor productivity (TFP) is one of the measures that the UK government uses to monitor the productivity of UK agriculture. In broad terms, it is an index based on the ratio of the value of all agricultural outputs to all inputs. It is calculated from the logarithm of the ratio of each input or output from one year to next, which is then weighted according to a moving average of the financial value of the input or output (Amadi et al. 2004). The TFP index of UK agriculture showed a steady annual rise between 1953 and 1984, with the exception of a decline associated with the drought of 1976. By contrast the index remained relatively static between 1984 and 2000 (Figure 5). Moreover, the TFP for the UK has tended to lag behind that of neighbouring countries (Table 2). This is in contrast to the data in Figures 2 and 3 which suggest that UK wheat and milk productivity has stayed similar to or exceeded that of neighbouring countries.

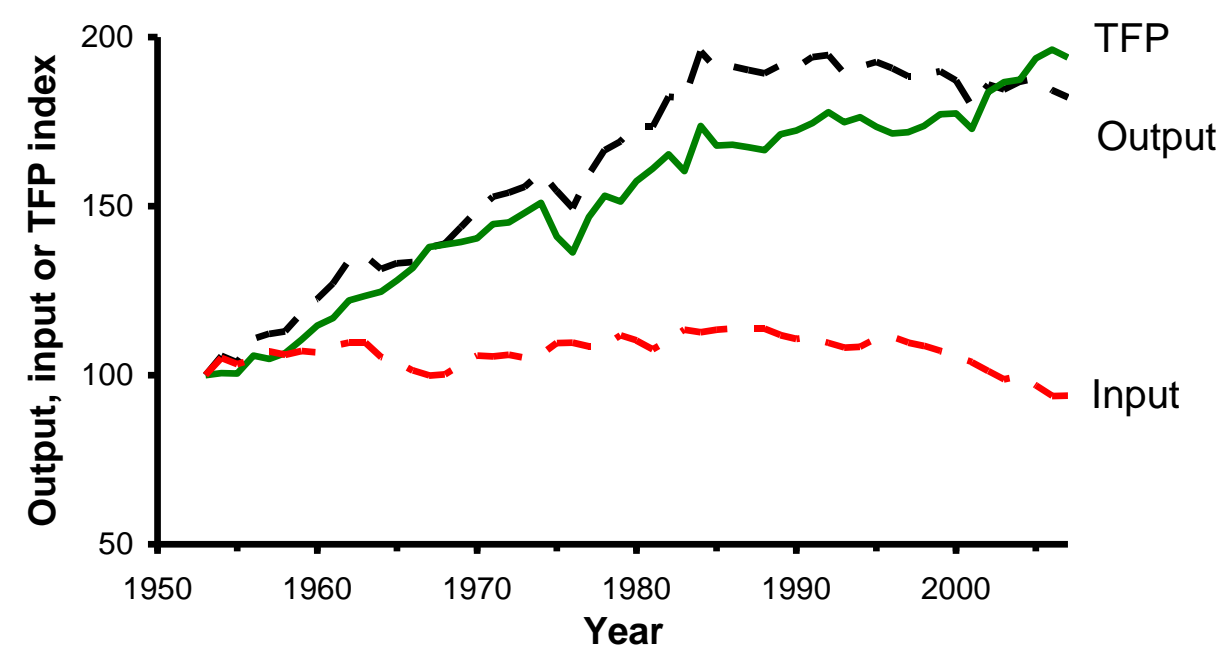

Figure 5 Levels of output index, input index and total factor productivity (solid-line: TFP) index for UK agriculture from 1953 to 2007 (1953=100) (Thirtle and Holding 2003; Defra, 2008).

Table 2. Examples of the calculated agricultural total factor productivity for selected countries (USA = 100 in 1996) (Defra, 2008).

\begin{tabular}{lrrcc}
\hline Year & Germany & France & Netherlands & UK \\
\hline 1974 & 48.6 & 47.6 & 78.5 & 50.1 \\
1984 & 60.3 & 56.5 & 78.9 & 59.5 \\
1994 & 63.3 & 64.4 & 93.4 & 58.1 \\
2002 & 69.4 & 71.4 & 94.8 & 63.2 \\
\hline
\end{tabular}

Some of the lack of productivity increase in UK agriculture between 1984 and 2000 can be explained by the particularly high cereal yields in 1984 (Figure 2), when good planting conditions in the autumn of 1983 were followed by a relatively cool and wet spring and a relatively dry harvest period. In 1996, the incidence of bovine spongiform encephalopthy (BSE) and the ban on beef exports severely affected the 
level of outputs from the beef sector. However the apparent stagnation in productivity could be misleading (Thirtle et al., 2004). Barnes (2002) explains that a "social" total factor productivity index, which includes external costs as those arising from nitrate and pesticide pollution, would reduce the rate of productivity increase observed between 1970 and the mid-1980s. Similarly, environmental improvements after 1984 have increased the "social" total factor productivity index relative to TFP index (Thirtle et al. 2004). Thirtle et al. (2004) also comment that the total factor productivity calculation assumes that technological changes have a similar effect on all inputs. In practice this is not the case, and over long periods this can cause substantial bias in the measures. If these biases are removed, Thirtle and Holding (2003) and Bailey et al. (2004b) show that the TFP index continues to increase after 1984. Such observations highlight the importance of using such an index with care.

The improvement in TPF between 2000 and 2006 was associated with a reduction in output being offset by a greater reduction in inputs such as fertiliser and labour. The data does not include the 2007-08 increase in cereal prices which, together with the curtailment of compulsory set-aside, induced an increased output of wheat of about 18 per cent on the previous three-year average, about 13 per cent of which was associated with increased plantings. This suggests two things - that farmers are responsive to price incentives and there is, at least for the moment, some reserve capacity in the farming sector.

\section{Potential areas of future technological development}

This section examines the potential for seven areas of technological innovation to impact changes in land use to 2050. The first three areas are genetic improvement, reducing abiotic and biotic stress, and increasing labour productivity (Figure 1; Table 3 ). The last four areas are changes in agricultural products, waste production, the effect on air, water and soil health and biodiversity, and information transfer (Figure 1; Table 3).

\section{Genetic improvement}

The yields of crops and animals are a function of the organism's genotype, the environment (including its management), and the interaction of the genotype with the environment. Sylvester-Bradley et al. (2005) suggest that current average UK wheat yields of about 8 tonnes per hectare could be increased by about 60 per cent to 13 tonnes per hectare by 2050. Cottrill et al. (2005) also consider that current rates of improvement in the yield potential of grass, clover and maize could be maintained. By contrast in some crops such as potatoes, the focus on quality has meant that current progress on increasing yields is small (Allen et al., 2005). Future yield increases in wheat may focus on increasing the photosynthetic rate during grain filling, in particular by focusing on the catalytic properties of the carbon dioxidefixing enzyme (Austin, 1999). There may also be opportunities to breed new varieties that can exploit the predicted increase in atmospheric carbon dioxide concentration. However, breeders will also focus on producing crop varieties or mixtures that are less dependent on agrochemicals, and more water and nutrient efficient (SylvesterBradley et al., 2005; Wolfe et al. 2008). 
Table 3. Seven areas within agricultural systems which can be affected by technological change, example technologies, typical aims in using the technology, and possible effects on land use.

\begin{tabular}{|c|c|c|c|}
\hline Area & Example technologies & $\begin{array}{l}\text { Typical aim in using the } \\
\text { technology }\end{array}$ & Effect on land use \\
\hline $\begin{array}{l}\text { 1. Genetic } \\
\text { improvement }\end{array}$ & $\begin{array}{l}\text { Plant and animal breeding } \\
\text { Genetic modification }\end{array}$ & $\begin{array}{l}\text { To increase yield and/or } \\
\text { quality per area of crop or per } \\
\text { animal, or per unit time }\end{array}$ & $\begin{array}{l}\text { Often incremental, but } \\
\text { product changes can } \\
\text { result in step-changes }\end{array}$ \\
\hline $\begin{array}{l}\text { 2. Reducing } \\
\text { abiotic and } \\
\text { biotic stress }\end{array}$ & $\begin{array}{l}\text { Crop nutrition and protection; } \\
\text { irrigation, drainage; animal } \\
\text { nutrition and health; housing } \\
\text { and habitat management }\end{array}$ & $\begin{array}{l}\text { To minimise yield and quality } \\
\text { losses due to stress and } \\
\text { injury; and to improve animal } \\
\text { welfare }\end{array}$ & Usually incremental \\
\hline 3. Labour & Mechanisation & To increase output per unit & Usually \\
\hline Productivity & Herbicides & $\begin{array}{l}\text { labour and improve the } \\
\text { timeliness of operations }\end{array}$ & Incremental \\
\hline $\begin{array}{l}\text { 4. New } \\
\text { agricultural } \\
\text { products }\end{array}$ & $\begin{array}{l}\text { Biomass for energy, } \\
\text { bioethanol, biodiesel and } \\
\text { biogas } \\
\text { Mediterranean crops } \\
\text { Health-based products } \\
\text { Change in product mix }\end{array}$ & $\begin{array}{l}\text { To develop new products or } \\
\text { products mixes in response to } \\
\text { new markets or } \\
\text { environmental change }\end{array}$ & Often a step change \\
\hline $\begin{array}{l}\text { 5. Reducing } \\
\text { waste }\end{array}$ & $\begin{array}{l}\text { Waste as energy } \\
\text { Waste as feedstocks } \\
\text { Plant and animal breeding } \\
\text { Food storage }\end{array}$ & $\begin{array}{l}\text { To minimise waste but to } \\
\text { maximise its value }\end{array}$ & $\begin{array}{l}\text { Usually incremental, } \\
\text { but regulation can } \\
\text { cause step-changes }\end{array}$ \\
\hline $\begin{array}{l}\text { 6. Enhancing } \\
\text { air, soil and } \\
\text { water quality } \\
\text { and } \\
\text { biodiversity }\end{array}$ & $\begin{array}{l}\text { Minimum tillage } \\
\text { Precision farming } \\
\text { Animal nutrition } \\
\text { Habitat management } \\
\text { Catchment sensitive farming }\end{array}$ & $\begin{array}{l}\text { To reduce net greenhouse gas } \\
\text { emissions and to enhance air, } \\
\text { water and soil quality and } \\
\text { farm biodiversity. }\end{array}$ & $\begin{array}{l}\text { Usually incremental, } \\
\text { but regulation can } \\
\text { cause step changes }\end{array}$ \\
\hline $\begin{array}{l}\text { 7. Information } \\
\text { transfer and } \\
\text { use }\end{array}$ & $\begin{array}{l}\text { Computerisation } \\
\text { Biosensors }\end{array}$ & $\begin{array}{l}\text { To improve decision making } \\
\text { by farmers and consumers }\end{array}$ & Usually incremental \\
\hline
\end{tabular}

In ruminant production, increasing low reproductive rates is likely to be a key target as 50 to 70 per cent of the food energy is required to maintain the parental population, compared to 4 per cent in broiler production (Sinclair and Webb, 2005). In the production of lean beef, the effective strategy of breeding and selecting larger and later-maturing cattle is likely to continue (Garnsworthy \& Thomas, 2005). A key feature of the current progress in pig breeding has been the use of unbiased statistical techniques and a move away from "pedigree" breeding (Wiseman et al., 2005). The genetic potential within aquaculture is seen as being particular great, as breeding has only had an impact on about 10 generations (Haley and Archibald, 2005).

During the 20th century, most breeding work was undertaken by identifying suitable parents within a species and selecting for desirable attributes amongst their progeny. New genetic technologies such as gene mapping and the use of gene markers have been helpful in streamlining the process of identifying and selecting individuals with desirable alleles (Haley and Archibald, 2005; Dennis et al. 2008). In many countries, plant breeders have also used genetic modification to transfer a desired gene from one 
individual to another without the risk of transferring possible undesirable genes. The process also allows desirable genes to be transferred from one species to another.

Gaskell et al. (2000) reports on a 1999 Eurobarometer survey (16,082 respondents) covering each EU state which showed that Europeans were not antagonistic to genetic technologies per se, but that the perceived "usefulness" of genetically modifying crops was balanced by perceived downside risks. In the case of genetically modified food and animal cloning, there was little appreciation of usefulness but a great appreciation of the risks. In 2004, the European Union lifted its moratorium on approving new genetically modified crops, which are examined on a case-by-case basis. However, general acceptance of genetic modification is likely to be dependent on the processes and products providing clear societal and environmental benefits (Dennis et al., 2008; O'Brien and Mullins, 2008). Moreover, where and when genetic modified crops are introduced, crop management practices such as length of rotation or unsprayed patches may be imposed as part of a package of measures to increase the ecological sustainability of the system (Firbank and Forcella, 2000; Dennis et al., 2008).

\section{Reducing abiotic and biotic stress}

In 2005, the non-genetic constraints to increasing UK wheat yields were considered to be largely economic and environmental rather than technological (Sylvester-Bradley et al., 2005). Low cereal prices at that time meant that farmers were applying lower amounts of potassium, phosphorus and sulphur than were required for maximum yields per hectare (Legg, 2005), or to replenish soil stocks (Potash Development Association, 2009). Looking forward to the next 50 years, greater attention is needed to the future availability and cost of nitrogen, potassium and phosphorus, which are closely related to oil and commodity prices (Piesse and Thirtle, 2009). Predicted reductions in summer rainfall could lead to a greater restriction on the availability of water for irrigation, and to changes in irrigation technology and crop selection (Knox and Weatherhead, 2005).

In all crop production systems, the reduction of weeds, pests and diseases potentially creates a dynamic ecological process which favours the development of resistant weeds, pest and diseases. So commercial farmers will continue to rely on the steady arrival of new technologies such as new fungicides and resistant crop varieties to counteract the natural selection of resistant strains. Technologies such as Integrated Pest Management and mixed cropping can also be useful in encouraging natural predators and reducing the selection pressure.

A key technological innovation to reduce stress and injury is to raise crops and animals in buildings where the environment can be regulated. Between 1960 and 1995, the proportion of inputs invested in buildings and land improvement increased between three- and four-fold (Thirtle et al., 2004). Similar developments may continue, while higher temperatures may increase the need for shading in livestock systems, either by using tree cover or buildings. One current example of building investment is the Thanet Earth development in Kent. Here the largest greenhouse complex in the UK is being constructed alongside a combined heat and power plant. The aim is to boost Britain's salad crop production by 15 per cent from this one site(Thanet Earth, 2009). As the government seeks to increase the use of combined heat and power, there will be similar opportunities at other locations. 
Within the livestock sector, reducing yield losses due to stress and injury is closely linked to animal welfare; for example mastitis and lameness are the principal reasons for the premature culling of dairy cattle (Garnsworthy and Thomas, 2005). Government regulation, such as the phasing out of the use of battery cages in egg production, can stimulate technological innovation and new land uses such as woodland-based egg-production systems. Similarly the introduction of the EU's integrated pollution prevention and control directive has made it extremely unattractive to establish pig units with more than 650 sows (Wiseman et al. 2005). Welfare could also become a key driver for genetic improvement, such as the selection of hens that show less cannibalism and pecking and greater bone strength (Hester, 2005). Although bovine somatotropin has been used to increase the milk yields of dairy cows in the USA, the use of this growth hormone is not permitted in the European Union on animal welfare grounds.

\section{Labour productivity}

There is little published research on predicted future changes in labour productivity. In the absence of other evidence, it is assumed here that the steady historical increase in productivity will continue. In some agricultural sectors it remains difficult to recruit staff and often labour is brought from outside the UK. In cropping systems, increases in labour productivity tend to be associated with wider cultivation equipment, sprayers and combines. In livestock production, labour productivity tends to increase with larger and more intensive systems, although such systems can face environmental, health and regulatory constraints. In the arable sector, the figures suggest appears that farm size and ownership are remaining relatively constant (Thirtle et al. 2004), but anecdotal evidence is that actual crop management is increasingly undertaken by larger farm businesses or contractors which can minimise machinery costs by working across a number of farms. One of the few areas where labour productivity may be stable is within individual allotments and gardens, where food production may be partly a recreational activity.

\section{New agricultural products}

The greatest changes in land use are often associated with the introduction of new products, or changes in the mix of existing products. For example, as mentioned earlier, the introduction of new baking technology encouraged the expansion of the UK wheat area, while the arrival of new varieties of oilseed rape with low concentrations of erucic acid and glucosinolates allowed the use of oilseed rape as an animal feed. Three key drivers of potential changes in the agricultural product mix are energy security, climate change, and health awareness.

Concerns over energy security and the need to reduce greenhouse gas emissions have created increased interest in the use of bioenergy crops. This could cause a step change in land use (Schmidhuber, 2006). Although the capacity to produce bioenergy is considered too small to affect energy prices, the energy market has created a floor price for many arable crops (Schmidhuber, 2006). As the world price for energy increases, the floor price for these crops also increases. (High energy prices also increase the cost of key agricultural inputs such as fertiliser and diesel). However, Schmidhuber also points out that if substantial quantities of land-based products are used in the energy sector, energy prices will also create a ceiling price for some commodities. For example, an oil-price reduction would reduce the amount of wheat 
converted to bioethanol and thereby reduce the wheat price. Assuming minimal government intervention, the net effect of these linkages on UK land use will depend on the relative costs and competiveness of UK bioenergy crops with internationallytraded bioenergy crops and fossil energy. Some early systems have focused on existing crops such as wheat, sugar beet and oilseed rape. However, breeding and research work is also piloting second-generation non-food perennial crops such as miscanthus, willow, and switchgrass which require fewer nutrients. In each case, the widespread uptake of such crops could have a major impact on land availability, water resources, and the landscape (Powlson et al., 2005).

In response to high concentrations of greenhouse gases, the UK appears to be experiencing higher temperatures and a decrease in summer rainfall (Jenkins et al., 2008). Such changes will favour new species to the UK such as sunflowers, and species which use the $\mathrm{C}_{4}$-phosynthetic pathway such as maize and miscanthus. In the horticulture sector, the UK could grow a wider selection of vegetable and fruit crops, and vineyards and orchards could become a more dominant feature in the British landscape. By contrast selected indigenous tree species, which form an important component of the British rural landscape, may decline in response to the changing climate and increased pressure from pests and diseases.

The third key driver in the future demand of agricultural products is human health. High levels of obesity, Type 2 diabetes and cardio-vascular diseases in the UK have been linked with a lack of exercise and unhealthy diets. Future crop varieties could focus on nutritional attributes such as a low glycaemic index or a particular amino acid or fatty acid combination (Dennis et al. 2008). Amongst other factors, a healthy diet is considered to have low levels of saturated fat Because more than half of the saturated fatty acids in the UK diet arise from animal-derived products, Cottrill et al. (2005) argue that breeding and management innovations should focus on improved fatty acid profiles in milk and meat products. Conversely, an increased emphasis on health, diet, and "ecological footprinting" could result in result in a greater emphasis on crop-based rather than animal-based products.

\section{Reducing waste}

Over the next 50 years, the term "waste" may become obsolete as technological innovation seeks to close the loops within agricultural systems. Many waste products can be used as energy feedstocks, and with suitable treatment some wastes can be used as organic fertilisers. There will also be a drive to reduce waste in the food chain. Whereas in the 1970s, about 6 per cent of total food was wasted in the home (Wenlock et al. 1980), it is now estimated that almost one third of household food purchases by weight are discarded as waste (WRAP, 2008), accounting for almost 20 per cent of the total tonnage of household waste. About half of this wasted food is fit for consumption (WRAP, 2008). It is estimated that a further 12 per cent is wasted within the food and drink industry, although some is recovered for other uses such as animal feed (Hyde et al., 2001). Technological innovations such as improving the shelf-life of food could reduce waste, but probably the greatest savings are to be achieved through changes in household purchasing behaviour and kitchen management (WRAP, 2008).

\section{Enhancing air, water, and soil quality and biodiversity}


Between 1985 and 2007, in a market where food prices were relatively low, the focus of public-funded research and technological innovation moved away from productivity enhancement to issues such as animal welfare and ways of improving air, water and soil quality, and biodiversity (Piesse and Thirtle, 2009). One example is precision farming, which can create environmental benefits from the better targeting of nitrogen applications (Welsh et al. 2003) and herbicides (Berge et al. 2009). Minimum or conservation tillage, whilst offering some benefits in terms of reduced labour costs, is also promoted as a way of improving carbon sequestration and soil fertility and biodiversity (Bradbury and Kirby, 2006). Other mechanisms to reduce pollution to water courses and increase biodiversity include the establishment of best management practices (Goulding et al. 2008), and the establishment of buffer strips and conservation areas.

Over the next 50 years, measures to reduce net carbon dioxide, nitrous oxide and methane emissions from agriculture will be particularly critical (Glendining et al., 2009), and the UK government has already set targets for the sector. Using US-based data between 1944 and 2007, Capper et al (2009) have shown how technological advances in dairying have reduced the amount of manure, methane and nitrous oxide to produce a given quantity of milk by 24 per cent, 43 per cent and 56 per cent respectively. Maintaining production from reduced animal numbers is seen as a key basis for reducing net emissions of greenhouse gases. There may also be a move towards indoor systems where animal wastes can be stored, and where nutritional inputs can be more closely matched to minimise nitrogen excretion (Garnsworthy, 2005).

\section{Information transfer and use}

Information transfer and use are likely to continue to be a key area of technological innovation. Innovations such as the internet can provide the farmer with a greater understanding of consumer requirements. Computer-based models and tools can also improve on-farm decision making regarding the use of fertilisers and organic manures (Goulding et al., 2008), planning crop-protection schedules, or formulating the most appropriate feed mix. But information is increasingly a key aspect of the product sold by the farm as well as being a management tool. At various points in the supply chain from the farmer, the supermarket and others will seek information such as the carbon footprint, the use of pesticides or medicines, and the location and time of production. Technologies such as electronic identification systems, which improve traceability in relation to livestock disease (Webb et al., 2005) and agrochemical use (Peets et al., 2009), may become more common. Consumers will also become increasingly aware of tools such as life cycle assessments (LCAs) which will allow them to compare the environmental impact and energy burden of different products or different agricultural systems such as conventional and organic agriculture (Williams et al. 2006; Day et al., 2008; Glendining et al. 2009).

\section{Capacity to release land from agricultural production}

The final section of this paper considers the combined effect of these technologies on a possible national need to take additional land into agricultural production, or the national capacity to release agricultural land for other uses. Glendining et al. (2009) have shown that for a specified output, relatively intense agricultural production is generally optimal for the environment because it does not necessitate the conversion 
of non-agricultural land with a high environmental value. Many of the technological innovations described above will increase land productivity and thereby (assuming a given demand) increase the proportion of land that can be released from agricultural production (Sylvester-Bradley and Wiseman, 2005). Such land can then be used to deliver other ecosystem services (Millennium Ecosystem Assessment, 2005) such as habitat conservation and opportunities for recreation and carbon sequestration.

Between 1992 and 2006, the reduced need to allocate land to crop production at a European level allowed between 5 and 10 per cent of the arable land to be "set aside", and the European Union was able to draw on this land bank after the increase in commodity prices of 2007-08. During the next 50 years, continued improvements in technology will be pivotal in providing flexibility in future land use decisions in the face of increased demands for crop and animal products. However, the amount of land released in lowland England and Wales and the implementation of technological change will also depend on government interventions and international trade (Table 4).

Table 4. Predicted effect of "Business as Usual" and four other intervention scenarios on the change in technical efficiency, self-sufficiency and the use of lowland agricultural land in England and Wales for agriculture, in 2050 relative to 2000-2004 values (derived from Morris et al., 2005).

\begin{tabular}{|c|c|c|c|c|}
\hline Scenario & Intervention regime & $\begin{array}{l}\text { Change in } \\
\text { technical } \\
\text { efficiency }^{\text {a }}\end{array}$ & $\begin{array}{l}\text { Change in self } \\
\text { sufficiency }^{\mathrm{b}}\end{array}$ & $\begin{array}{l}\text { Change in } \\
\text { land use for } \\
\text { agriculture }\end{array}$ \\
\hline $\begin{array}{l}\text { Business as } \\
\text { usual }\end{array}$ & Agricultural support as in 2002 & +19 per cent & +6 per cent & -20 per cent \\
\hline $\begin{array}{l}\text { World } \\
\text { markets }\end{array}$ & Zero: market-driven free trade & +34 per cent & -3 per cent & -34 per cent \\
\hline $\begin{array}{l}\text { National } \\
\text { enterprise }\end{array}$ & $\begin{array}{l}\text { Moderate to high: protected domestic } \\
\text { markets with limited environmental } \\
\text { concern }\end{array}$ & +39 per cent & +26 per cent & -18 per cent \\
\hline $\begin{array}{l}\text { Global } \\
\text { sustainability }\end{array}$ & $\begin{array}{l}\text { Low: market orientation with } \\
\text { targeted sustainability compliance }\end{array}$ & +12 per cent & +8 per cent & -2 per cent \\
\hline $\begin{array}{l}\text { Local } \\
\text { stewardship }\end{array}$ & $\begin{array}{l}\text { High: locally defined schemes } \\
\text { reflecting local priorities }\end{array}$ & -7 per cent & +23 per cent & 0 per cent \\
\hline \multicolumn{5}{|c|}{$\begin{array}{l}\text { a Mean technical efficiency (i.e. yield per hectare or yield per head) for five crop and five livestock } \\
\text { commodities (pg 29; Morris et al. 2005). } \\
\text { b Mean level of self-sufficiency expressed as the ratio between production and consumption of twelve } \\
\text { commodities (page 49; Morris et al. 2005). }\end{array}$} \\
\hline
\end{tabular}

Morris et al. (2005) as part of a study of "Agricultural Futures and Implications for the Environment" estimated agricultural changes in England and Wales by 2050 assuming that government intervention and international trade continued as if it was "Business as Usual" (Table 4). Relative to the "Business as Usual" scenario, and assuming no energy cropping, a greater focus on free trade (World Markets Scenario) was associated with additional increases in technical efficiency and about a third of current lowland agricultural land was predicted to be released from production. A protectionist trade policy (the National Enterprise scenario) was also predicted to increase technical efficiency and self-sufficiency and to release about 18 per cent of lowland agricultural land from intensive production. In the last two scenarios (Global Sustainability and Local Stewardship), self sufficiency was predicted to increase, but 
constraints on the increase in technical efficiency meant that all current lowland agricultural land would be required for agriculture. There is probably a need to update this research in the light of recent developments, but the overall analysis highlights a generally positive relationship between increased agricultural technology and the national capacity to release agricultural land for other uses.

\section{Conclusions}

Technological innovations which improve the efficiency with which land and other resources are used are probably the most useful tools we have as we seek to manage the balance between the well-being of people and the maintenance of the global ecosystem. Public and private investment in improved agricultural technology is critical if future generations are to have flexibility in decisions regarding land use.

We do not know how global agricultural production will be affected by future changes in climate, and in the trade policies of national governments. In addition, the interactions between technological innovation, food security and the proportion of UK land released for other uses are complex. However, the spike in the price of commodities between 2007 and 2008 provides a stark reminder of the advantages of retaining capacity within the UK agricultural system.

The relatively low food prices of the past 20 years have allowed society to focus on the multifunctional nature of agricultural land use. In such an environment, IAASTD (2009) has argued that appropriate implementation of agricultural technology (for example genetic modification of crops or the introduction of biofuels) requires governmental facilitation of interactive stakeholder networks. Such workshops will continue to be essential in the future.

In the UK, technological innovation has been particularly successful in improving labour productivity. However, the published research on labour productivity is sparse compared to the technical issues. In addition, current methods and tools for comparing the relative productivity of agriculture in the UK with that in other countries can raise as many questions as they answer.

Future technological advances can be divided into two categories: incremental and step changes. With appropriate investment, it would appear possible to maintain incremental increases in crop and animal yields, in soil and water quality, and in farmland biodiversity. By contrast, changes in the mix of products being produced can cause step changes in land-use. Three key areas are:

- The market for bio-energy based on existing crops, bespoke energy crops and agricultural waste.

- The direct effects of climate change on UK production and production in countries from which we currently import food, together with the effects of regulations to control greenhouse gas emissions in the agricultural sector.

- Whilst it is difficult to change human nature, there may yet be step changes in the diet of the UK population, as well as opportunities to reduce the current high levels of food waste.

\section{Acknowledgements}

We acknowledge helpful advice from two anonymous reviewers. 


\section{References}

Allen, E.J., Allison, M.F. \& Sparkes, D.L. (2005). Physiological and technological limits to yield improvement of potatoes. In: Yields of Farm Species: Constraints and Opportunities for the $21^{\text {st }}$ Century. 289-309. (Eds. R. Sylvester-Bradley and J. Wiseman). Nottingham: Nottingham University Press.

Amadi, J., Piesse, J. \& Thirtle, C. (2004). Crop level productivity in the eastern counties of England, 1970-97. Journal of Agricultural Economics 55: 367-383.

Austin, R.B. (1999). Yield of wheat in the United Kingdom: recent advances and prospects. Crop Science 39: 1604-1610.

Austin, R.B., Bingham, J., Blackwell, R.D., Evans, L.T., Ford, M.A., Morgan, C.L. \& Taylor, M. (1980). Genetic improvements in winter wheat yields since 1900 and associated physiological changes. Journal of Agricultural Science Cambridge 94: 675-685.

Bailey, A., Balcombe, K., Thirtle, C. \& Jenkins, L. (2004a). ME Estimation of input and output biases of technical and policy change in UK agriculture. Journal of Agricultural Economics 55: 385-400.

Bailey, A., Irz, X. \& Balcombe, K. (2004b). Measuring productivity growth when technological change is biased - a new index and an application to UK agriculture. Agricultural Economics 31: 285-295.

Barnes, A.P. (2002). Publicly-funded UK agricultural R\&D and 'social' total factor productivity. Agricultural Economics 27: 65-74.

Berhout, F., Eames, M. \& Skea, J. (1998). Environmental Futures Scoping Study. Brighton: SPRU.

Berge, T.W., Cederkvist, H.R., Aastveit, A.H. \& Fykse, H. (2009). Simulating the effects of mapping and spraying resolution and threshold level on accuracy of patch spraying decisions and herbicide based on mapped weed data. Acta Agriculturae Scandinavica Section B - Soil and Plant Science 58: 216-229.

Bradbury, R.B. \& Kirby, W.B. (2006). Farmland birds and resource protection in the UK: cross-cutting solutions for multi-functional farming? Biological Conservation 129: 530-542.

Capper, J.L., Cady, R.A. \& Bauman, D.E. (2009). The environmental impact of dairy production: 1944 compared with 2007. Journal of Animal Science 87: 21602167.

Cottrill, B.R., Gooding, M.J. \& Givens, D.I. (2005). Nutritional value and yield of forages for livestock: means or limitations to increasing animal production. In: Yields of Farm Species: Constraints and Opportunities for the $21^{\text {st }}$ Century. 545576. (Eds. R. Sylvester-Bradley and J. Wiseman). Nottingham University Press

Day, W., Audsley, E., \& Frost, A.R. (2008). An engineering approach to modelling, decision support and control for sustainable systems. Philosophical Transactions of the Royal Society B 363: 527-541.

DEFRA (2008). Agriculture in the UK 2007: Tables and Charts. Accessed 12 March 2009. https://statistics.defra.gov.uk/esg/publications/auk/2007/excel.asp

Dennis, E.S., Ellis, J., Green, A., Llewellyn, D., Morell, M., Tabe, L., \& Peacock, W.J. (2008). Genetic contributions to agricultural sustainability. Philosophical Transactions of the Royal Society 363: 591-609.

Eastridge, M.L. (2006). Major advances in applied dairy cattle nutrition. Journal of Dairy Science 89: 1311-1323.

FAO (2009). FAOSTAT Crop and Livestock Production data. Accessed 9 March 2009. http://faostat.fao.org/site/567/default.aspx\#ancor 
Firbank, L.G. \& Forcella, F. (2000). Genetically modified crops and farmland biodiversity. Science 289: 1481-1482.

Frame, J., Baker, R.D. \& Henderson, A.R. (1995). Advances in grassland technology over the past fifty years. In: Grassland into the $21^{\text {st }}$ Century: Challenges and Opportunities 31-63. Proceedings of the $50^{\text {th }}$ Anniversary Meeting of the British Grassland Society.

Garnsworthy, P.B. (2005). Livestock yield trends: implications for animal welfare and environmental impact. In: Yields of Farm Species: Constraints and Opportunities for the $21^{\text {st }}$ Century. 379-401. (Eds. R. Sylvester-Bradley and J. Wiseman). Nottingham University Press.

Garnsworthy, P.C. \& Thomas, P.C. (2005). Yield trends in UK dairy and beef cattle. In: Yields of Farm Species: Constraints and Opportunities for the $21^{\text {st }}$ Century. 435-462. (Eds. R. Sylvester-Bradley and J. Wiseman). Nottingham University Press.

Gaskell, G., Allum, N., Bauer, M., Durant, J., Allansdottie, A., Bonfadelli, H. Boy, D., de Chveigné, S., Fjaestad, B., Gutteling, J.M., Hampel, J., Jelsøe, E., Correia Jesuino, J., Kohring, M., Kronberge, N., Midden, C., Nielsen, T.H., Przestalski, A., Rusanen, T., Sakellaris, G., Torgersen, H., Twardowski, T. \& Wagner, W. (2000). Biotechnology and the European public. Nature Biotechnology 18: 935938.

Glendining, M.J., Dailey, A.G., Williams, A.G., van Evert, F.K., Goulding, K.W.T. \& Whitmore, A.P. (2009). Is it possible to increase the sustainability of arable and ruminant agriculture by reducing inputs? Agricultural Systems 99: 117-125.

Goulding, K., Jarvis, S. \& Whitmore, A. (2008). Optimizing nutrient management for farm systems. Philosophical Transactions of the Royal Society 363: 667-680.

Haley, C.S. \& Archibald, A.L. (2005). Livestock - genomics and productivity. In: Yields of Farm Species: Constraints and Opportunities for the $21^{\text {st }}$ Century. 417434. (Eds. R. Sylvester-Bradley and J. Wiseman). Nottingham University Press

Hester, P.Y. (2005). Impact of science and management on the welfare of egg laying strains of hens. Poultry Science 84: 687-696.

Hyde, K., Smith, A., Smith, M. \& Henningsson, S. (2001). The challenge of waste minimisation in the food and drink industry: a demonstration project in East Anglia, UK. Journal of Cleaner Production 9: 57-64.

IAASTD (International Assessment of Agricultural Knowledge, Science and Technology for Development) (2009). Summary for Decision Makers of the North America and Europe (NAE) Report. Washington: Island Press. 30 pp.

Jenkins, G.J., Perry, M.C. \& Prior, M.J. (2008). The Climate of the UK and Recent Trends. Meteorological Office, Hadley Centre, Exeter.

Knox, J.W. \& Weatherhead, E.K. (2005). The growth of trickle irrigation in England and Wales: data, regulation and water resource impacts. Irrigation and Drainage 54: 135-143.

Lang, B. (2004). Report on farming in the Eastern Counties of Eastern England 2003/2004. University of Cambridge.

Legg, B.J. (2005). Crop improvement technologies for the $21^{\text {st }}$ Century. In: Yields of Farm Species: Constraints and Opportunities for the $21^{\text {st }}$ Century. 31-50. (Eds. R. Sylvester-Bradley and J. Wiseman). Nottingham University Press.

Millennium Ecosystem Assessment (2005). Ecosystems and Human Well-Being Synthesis. Washington: Island Press. 137 pp. 
Morris, J., Audsley, E., Wright, I.A., McLeod, J., Pearn, K., Angus, A. and Rickard, S. (2005). Agricultural Futures and Implications for the Environment. Defra Project IS0209. Bedfordshire: Cranfield University.

O'Brien, M. \& Mullins, E. (2009). Relevance of genetically modified crops in light of future environmental and legislative challenges to the agri-environment. Annals of Applied Biology 154: 323-340.

Peets, S., Gaspain, C.P., Blackburn, D.W.K., \& Godwin, R.J. (2009). RFID tags for identifying and verifying agrochemicals in food traceability systems. Precision Agriculture. In press. DOI:10.1007/s11119-009-9106-4.

Piesse, J. \& Thirtle, C. (2009). Three bubbles and a panic: an explanatory review of recent commodity price events. Food Policy 34: 119-129.

Potash Development Association (2009). Nutrient management risks for major crops. Potash News July 2009. York: Potash Development Association. 2 pp.

Powlson, D.S., Richie, A.B. \& Shield, I. (2005). Biofuels and other approaches for decreasing fossil fuel emissions from agriculture. Annals of Applied Biology 146: 193-201.

Pryce, J.E., Royal, M.D., Garnsworthy, P.C. \& Mao, I.L. (2004). Fertility in the high producing dairy cow. Livestock Production Science 86: 125-135.

Robinson, R.A. \& Sutherland, W.J. (2002). Post-war changes in arable farming and biodiversity in Great Britain. Journal of Applied Ecology 39: 157-176.

Russell-Eggitt, P.W. (1977). Choosing between crops: aspects that affect the user. Philosophical Transactions of the Royal Society of London B: 281: 93-106.

Schmidhuber, J. (2006). Impact of an increased biomass use on agricultural markets, prices and food security: a longer-term perspective. Paper presented at the International Symposium of Notre Europe, Paris 27-29 November 2006.

Sylvester-Bradley, R., Foulkes, J. \& Reynolds, M. (2005). Future wheat yields: evidence, theory and conjecture. In: Yields of Farm Species: Constraints and Opportunities for the $21^{\text {st }}$ Century. 233-260. (Eds. R. Sylvester-Bradley and J. Wiseman). Nottingham University Press.

Sylvester-Bradley, R. and Wiseman, J. (2005). Yields of UK Crops and Livestock: physiological and technological constraints, and expectations of progress to 2050: Defra Project IS0210, ADAS/Nottingham University. Boxworth, Cambridge.

Sinclair, K.D. and Webb, R. (2005). Reproductive rate in farm animals: strategies to overcome biological constraints through the use of advanced reproductive technique. In: Yields of Farm Species: Constraints and Opportunities for the $21^{\text {st }}$ Century. 51-87. (Eds. R. Sylvester-Bradley and J. Wiseman). Nottingham University Press.

Stoate, C., Boatman, N.D., Borralho, R.J., Rio Carvalho, C. , de Snoo, G.R. \& Eden, P. (2001). Ecological impacts of arable intensification in Europe. Journal of Environmental Management 63: 337-365.

Thanet Earth (2009). A New Horticultural Future. Accessed 12 March 2009. http://www.thanetearth.com/

Thirtle, C., and Holding, J. (2003) Productivity in UK Agriculture: Causes and Constraints. Report to Department for Environment, Food and Rural Affairs. Wye, Kent: Imperial College.

Thirtle, C., Lin, L., Holding, J., Jenkins, L., \& Piesse, J. (2004). Explaining the decline in UK agricultural productivity growth. Journal of Agricultural Economics 55: 343-366.

Webb, R., Stubbings, L., Gregson, K. \& Robinson, J.J. (2005). Yield of sheep: physiological and technological limitations. In: Yields of Farm Species: 
Constraints and Opportunities for the $21^{\text {st }}$ Century. 463-494. (Eds. R. SylvesterBradley and J. Wiseman). Nottingham University Press.

Welsh, J.P., Wood, G.A., Godwin, R.J., Taylor, J.C., Earl, E., Blackmore, S., \& Knight, S.M. (2003). Developing strategies for spatially variable nitrogen application in cereals, part 1: winter barley. Biosystems Engineering 84: 481494.

Wenlock, R.W., Buss, D.H., Derry, B.J. \& Dixon, E.J. (1980). Household food wastage in Britain. British Journal of Nutrition 43: 53-70.

Westmacott, R. \& Worthington, T. (1994). Agricultural Landscapes: a Third Look. Countryside Commission.

Williams, A.G., Audsley, E. \& Sandars, D.L. (2006). Determining the Environmental Burdens and Resource Use in the Production of Agricultural and Horticultural Commodities. Main report. Defra Research Project IS0205. Bedfordshire; Cranfield University.

Wiseman, J., Varley, M., Knowles, A. \& Walters, R. (2005). Livestock yields now, and to come: case study pigs. In: Yields of Farm Species: Constraints and Opportunities for the $21^{\text {st }}$ Century. 495-517. (Eds. R. Sylvester-Bradley and J. Wiseman). Nottingham University Press.

Wolfe, M.S., Baresel, J.P., Desclaux, D., Goldringer, I., Hoad, S., Kovacs, G., Löschenberger, F., Miedaner, T., Østergård H. \& Lammerts van Bueren, E.T. (2008). Developments in breeding cereals for organic agriculture. Euphytica 163: 323-346.

WRAP. (2008). The Food We Waste. Project RBC 405-0010. ISBN 1-84405-383-0, July 2008, WRAP-Waste and Resource Action Plan; Banbury. 